\title{
Traçando mapas: a teoria histórico-cultural e as contribuições para a pesquisa com crianças e suas espacialidades ${ }^{\star}$
}

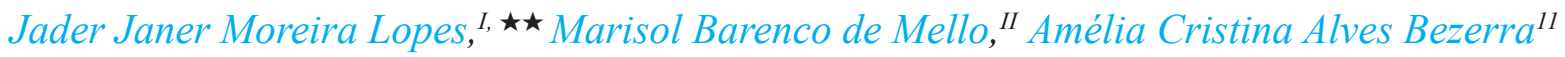 \\ ${ }^{I}$ Federal University of Juiz de Fora, Juiz de Fora, MG, Brazil \\ ${ }^{I I}$ Fluminense Federal University, Niterói, RJ, Brazil
}

\begin{abstract}
Resumo
Este texto busca fazer uma reflexão sobre as pesquisas sistematizadas no campo da infância, tendo como enfoque principal as estratégias de pesquisas "com crianças." O recorte ao qual nos dedicamos são as relações que as crianças estabelecem com o meio, tendo como foco principal as suas espacialidades. A partir das contribuições de pesquisas que se aportam em estratégias de natureza qualitativas e fundamentadas nos aportes da teoria históricas cultural, elege-se o conceito de vivência (perejivanie) como mote em torno do qual nossos trabalhos são desenvolvidos. Para isso, traça-se, inicialmente, a origem da pesquisa com base em paradigmas positivistas e evidenciam-se alguns caminhos que buscaram romper com essa perspectiva: os postulados etnográficos de Malinovky e Boas; o Interacionismo simbólico, cujo precursor é George Herbert Mead; a Etnometodologia de Harold Gatfinkel; as contribuições de Marx e os princípios estabelecidos por Vigotski e seus colaboradores.
\end{abstract}

Palavras-chave: crianças; vivências; espacialidades.

\section{Drawing maps: historical-cultural theory and contributions to research with children and spatiality}

\begin{abstract}
This paper seeks to reflect on systematized research in the field of childhood, which primarily focuses research strategies "with children." The main focus is on the relationships that children establish with the environment, specifically, their spatialities. Starting from the contributions of research that provide qualitative strategies and on the basis of the contributions of the cultural historical theory, we elect the concept of life experience (perezhivanie) as the main point, around which our study is developed. Therefore, the origin of research based on the positivist paradigm is traced and some paths that tried to break away from this perspective are suggested: the ethnographic hypotheses of Malinovsky and Boas; the symbolic interactionism, whose precursor is George Herbert Mead; the Ethnomethodology of Harold Garfinkel; the contributions of Marx and the principles laid down by Vygotsky and his collaborators.
\end{abstract}

Keywords: children; experiences; spatiality.

"Man is a defenseless creature, which shouldn't exist. We shouldn't spend much time observing him. It's the only figure which makes us dizzy if we watch him too much He's too tall when we look up, and our eyes can't take him all in at once." Conversa de Bois - Guimarães Rosa

"And what were you doing there?" was the question we asked one of the children who was telling us about how they, with his other friends, had been chased by a dog-one of those rough mutts. Enthusiastically, he said that he and the others had entered a plot of land to steal some mangoes - after all, "the branch was full of them" but no one expected the dog to be there.

In a circle, the other children listened and laughed at the stories we were being told, and nearly always, someone remembered similar previous instances. This was how Thaís told us that they were picking guavas in a neighbor's yard like magpies. Marcos and his friends went out on their bikes and returned very late, which earned them a big punishment, and Mauro told us that his grandmother had passed out near the pool at the house where they lived as caretakers, and it was he who ran to call his mother.

\footnotetext{
^ Grupo de Pesquisa e Estudos em Geografia da Infância [Research and Study Group in Childhood Geography] (GRUPEGI/CNPq), Coordinated by Jader Janer Moreira Lopes.

$\star \star$ Address for correspondence: Federal University of Juiz de Fora, Faculty of Education. Federal University of Juiz de Fora (Campus UFJF) - São Pedro. CEP: 36036900 - Juiz de Fora, MG — Brazil. E-mail: jjaner@pq.cnpq.br, sol. barenco@gmail.com, amelliacristina@uol.com.br.
}

We were organizing meetings through which we tried to understand the concepts and representations of spaces migrant children had. ${ }^{1}$ In a field diary, we drafted some typical initial questions at the start of a research project:

- what were their names?

- how old were they?

- where did they live at the moment?

- $\quad$ had they lived anywhere else before?

These words were useful to initiate conversations that rapidly shifted to the space and time in their life stories.

At the same time, we were interested in conducting a bibliographical sweep to collect information about the displacement of children to Brazil since colonialism. The texts revealed that those children and young people's migration processes had started with Portuguese colonialization itself in our territory, as was recorded in reports from the era that pointed to the presence of children among the crews who had made the sea crossing, which aroused our interest in knowing more about the situation of the children of that era.

\footnotetext{
${ }^{1}$ This text comes from the research Então Somos Mudantes [So we are Creatures of Change]. Post-Graduate Program In Education - Masters and Doctorate/Faculty of Education/ Fluminense Federal University. Access to the complete text at: http://geografiadainfancia.blogspot.com.br/
} 
In another study, we were trying to understand the changes in representations of the world in children aged between six and eight years, in the process of acquiring literacy, in terms of their interaction with spatial information aids (e.g., maps and globes).

The episode illustrated below is part of a dialogue that takes place about the globe that is placed in the class as a cultural object to trigger different dialogues between adults and children. In the dialogue, $\mathrm{C}$ are the children and $\mathrm{A}$ are the participating adults :

C - Look lady, the world spins like this... (spins the globe in an anticlockwise direction)

A - Spinning?

A - Yeah, but it doesn't spin this way, no, it spins that way (shows the arrows in the direction of the rotation, below the Equator).

$\mathrm{C}-$ So you have to spin it slowly... [...]

$\mathrm{C}$ - Let the world spin...

A- But the world doesn't spin quickly like this, no. Otherwise we'd be thrown off.

A - Where are we, then?

$\mathrm{CC}-\mathrm{Here}$ ! Here and here... (they indicate various places on the globe

A - Where are the people?

$\mathrm{CC}$ - Here, here, here, here...

A - Where are the people, are they on the inside or the outside?

$\mathrm{C}$ - Inside.

A - Inside it?

$\mathrm{C}$ - Outside.

C - Here, lady. (Shows the surface of the globe)

$\mathrm{C}$ - Over here (shoes the surface of the countries) [...]

A - Let me show Fabiano something, here (reading) the direction of the Earth's rotation, is that way. But it doesn't spin quickly, it spins very slowly. Can you feel it spinning? Can you feel it spinning here, now, where are we here?

C - (spins many times) I'm ... (MELLO, 2003, pg. 220-221).

In the episode that was filmed and analyzed, we observed that the children use different expressive modalities to posit their arguments in the dialogue; verbal creation, reading (of symbols and words), and gestures. We also studied how culturally created spatial representations interfere with childrens' spatial concepts, and that they are expressed in multiple types of graphic, verbal, and gestural representations and play.

These accounts are part of what the Research and Study Group in Childhood Geography [Grupo de Pesquisas e Estudos em Geografia da Infância] (GRUPEGI/CNPq) focus on, they aim not only on systematizing their concepts and bringing the spatial debate about children and their childhood to contemporary studies but also to reflect on the methodological challenges that work impose. The challenges are numerous; as we are trying to centralize childrens' creativity and expression, subjects who, until very recently, were not understood as holders of logic and rational discourse. Moreover, the challenges arising from research in human sciences that are far from being well resolved, present themselves daily as a need for discussion. Our research aims to understand the ways children understand the world expressed in maps, text, verbal discourse, games, drawings, gestures etc., affirming the child as an individual of and in culture, in training processes that arise in social and historical contexts of which they are a part of and with ones they interfere with.

How can we find ways to create this research? The questions that lead to the creation of research are generally followed by others: which way should we go? up to where, when, and how much should we research? how can we select the research group?

The act of research is a work that involves searching for interpretations, the recognition of crossing the line between the side of the researchee and the researcher, a situation that eternally places us in a situation of doubt and therefore brings us closer to migrant subjectivity, whose departure from a place tears away their certainties and drives them to a wanderer's life in search of the unknown.

Therefore, a well-drawn project can be compared to maps that take us on routes to reach particular destinations and safely guide us during the journey. However, this cannot mean a closed road that prevents us from seeing other paths that appear during the research, as the possibility should exist to recontextualize the project from the experiences shared by the participants in the study. A situation that has occurred with various [...] researchers such as Evans-Pritchard in his work with the Azande: "I wasn't interested in witchcraft when I went to Zande, but the Azande were; so I had to allow myself to be guided by them" (LOPES, 1998, pg. 100).

Thus, walking alongside the researcher becomes possible in a science proposal, which, by having men, women, and/or children as the center of their analysis, understands that we are interacting with another side that "has a voice, which is alive and feels its humanity by establishing dialogue" (LOPES, 1998, pg. 23). Furthermore, this relationship is not "a researcher/object relationship, but a relationship between live beings, who, even when disguised by their labels are dialogic, they feel the weight of humanity and can only be understood in that perspective" (LOPES, 1998, pg. 23). In the words of Bakhtin (1992, pg. 403):

Exact sciences are a monological type of knowledge: the intellect contemplates something and expresses his opinion on it. There is only one subject: he who practices the act of cognition (of contemplation) and speaks (expresses his opinion). Before him, there is a mute object; any object of knowledge (including man) can be understood and recognized as a thing. However, a subject cannot be understood and studied as a thing because, as a subject, it cannot stay mute; consequently, the knowledge we have of him can only be dialogic. 
The notion of science in the modern era emerges as one of the forms of sustaining a new way of thinking in Europe, opposing religious-feudal thinking that had been predominant until then.

This systematization took place during the 19th Century, which was supported by Darwin's ideas about evolution, linked to the thinkings of Bacon, Descartes, Comte, etc., and contributed to the organization a new way of understanding and explaining the world and its phenomena.

This paradigm, known as positivist and evolutionist, becomes the approach in all fields of knowledge that tried to organize themselves as science and which, to achieve such status, should encourage

a) logic in experiments: logic would be the defining aspect of science itself;

b) universal laws: events are explained through deductive models using statistical data;

c) a neutral researcher: there is an emphasis on directly observable phenomena; any illogical situation is considered a metaphysical absurdity. Every effort is made to eliminate the researcher's influence on the work.

On the basis of these hypotheses and findings in the sources of scientific status, human sciences try to study man through natural laws and mathematical models, and the researcher's neutrality, ignoring all of society's cultural, historical, and dynamic character.

In the meantime, still in the 19th Century, the attempt to understand the social realities that took shape on the Earth's surface ended up looking beyond appearance and basing themselves on the essences that made them dynamic; the relationships established between people, and their organization, could not be ignored. However, how could we learn about them in a concept centered on a social vacuum?

All of these factors triggered a number of research projects that analyzed this new reality. From this discussion, other investigative approaches arose in the fields of human sciences that tried to break through the current methodology and structure a new path, distancing itself from positivism and becoming closer to other concepts of knowledge such as hermeneutics, phenomenology, and historical materialism.

This new type of knowledge that tried to uncover the fabric of society that produces subjectivity when constructing an imaginary and collective individual, would go on to influence the groups that dedicated themselves to organizing a new paradigm for human sciences, establishing paths and characteristics for this new approach, which became known to some as qualitative. ${ }^{2}$

Bogdan and Biklen (1984) use the word umbrella to name this concept as it has inputs from numerous strands such as anthropology, sociology, symbolic interactionism, and ethnomethodology.

\footnotetext{
The varies from author to author, some consider this new way of thinking "qualitative" (since it tries to break through the quantitative hypothesis of positivism). Others consider it "interpretative" (as its aim is to interpret the researcher and not simply measure facts or the negation or proof of a hypothesis); moreover, others consider it "naturalístic" (it studies phenomena in their natural environment, in the context where they are occurring).
}

From Malinovsky, we inherit the ethnographic hypothesis; from Boas, the concept of all, wherein all of society's artifacts make sense when they are understood in their own reality. It is from Max Weber that we get the idea that in human sciences, "the subject and the object are identical [...], since both are gifted with conscience and historicity" (FONTES, 1997, pg. 126) grounded in the adoption of values, typical of the human being. Thus, scientific neutrality is also something questionable since "the choice of the object of the study itself (the theme, the problem to be worked on) constitutes an option, which is generally dictated by an affinity to values." (FONTES, 1997, p. 126). Fontes proposes that human sciences center their method on comprehension and not on explanation (a typical path in natural sciences).

The symbolic interactionism presupposes the idea of society as something dynamic and not static, which arises from the interaction between the subjects of which it is comprised. In this concept, the idea of the individual appears linked to a context, the understanding of the world occurs from the environment to which that individual belongs, and the relationships established with other individuals. One of the main precursors of this hypothesis is George Herbert Mead (1863-1931), who, although he did not produce a complete work about his ideas, greatly contributed to the systematization of that line of thinking. For this theorist, man's behavior arises from the intentions of others, transmitted through movements and situations that are symbolic and open to interpretation, human activity being, therefore, mediated by interpretation.

Ethnomethodology is a sociological hypothesis that appeared in the 1940s with Harold Garfinkel's academic studies. ${ }^{3}$ Working on material collected over a two-year period about homicides and conviction proceedings, he began coining his theories. For Garfinkel, every individual belonging to a community end up developing their knowledge about the environment that surrounds them. Borrowing from William Thomas' idea that people are active parts in the definition of the situation in which they live, which presents as an ethnomethodological proposal to the search for understanding of how individuals "together see, describe and propose a definition of the situation." (COULON, 1987, pg. 20).

Marx's theoretical suppositions establish a solid framework in displacing the historical dynamic to a material relationship (breaking away from the notion of supreme force and the absolutist idea posited by Hegel), which establishes the idea of production. The basis for Marx's humanism lies in his analysis of man as a social animal who works (an elastic term, which should in no way be identified as simply a capitalist notion and we would normally use it); thus, this creates and reproduces his existence in his day-to-day actions. In "Preface to A Contribution to the Critique of Political Economy," Marx (1859, online) states

[...] In the social production of their existence, men inevitably enter into definite relations, which are

${ }^{3}$ Garfinkel's ideas are strongly influenced by phenomenology, above all through the concepts of Edmund Husserl, Aaron Gurwitsch, Alfred Schütz, and Maurice Merleau-Ponty.

Fractal, Rev. Psicol., v. $27-\mathrm{n}^{\circ}$. 1, pg. 28-32, 2015 
independent of their will, namely relations of production appropriate to a given stage in the development of their material forces of production. The totality of these relations of production constitutes the economic structure of society, the real foundation, on which arises a legal and political superstructure and to which correspond definite forms of social consciousness. The mode of production of material life conditions the general process of social, political and intellectual life. It is not the consciousness of men that determines their existence, but their social existence that determines their consciousness. [...].

From his ideas, we can gauge a different outlook for the researcher, an outlook that tries to recognize, in the visible folds of the reality that is presented, the intricate network of relationships of which it is comprised-dynamic in space and time. A way of getting to know something that reveals the social conditions that produce the material. For Franco (1998, verbal information), "to know an object is to reveal its social structure."

These different research strategies converge into some common characteristics. Bogdan and Biklen (1994) define five points with shared traits in these procedures:

1. the researcher is the key instrument, although he uses videotape and other material, it is necessary for him to be in the field of work to learn the reality being studied;

2. qualitative research is descriptive, data is verbally collected. The data include interviews, transcriptions, notes, photographs, videotapes, and personal documents; all the details and situations are important in making sense;

3. qualitative researchers are more concerned with the process than the product: the researcher should center his understanding in the dynamic that is processed in everyday life, which should be the center of his analysis;

4. qualitative research tends to inductively analyze its data: the researcher should not be concerned with finding evidence that proves hypotheses that have already been established; the process should be the exact opposite, the understanding and abstraction should part from the proof obtained;

5. the meaning that individuals attribute to things is of fundamental interest to qualitative work: one of the researcher's concerns should be to understand how people understand themselves and the world that surrounds them.

Created in the Russian post-revolution era, at a time when the Union of Soviet Socialist Republics was being organized, represented by well-known psychologists such as Lev Semyonovich Vygotsky, Aleksei Nikolaevich Leontiev, and Alexander Romanovich Luria, a group led by Vygotsky, tried to systematize another way of conceiving the human being and its own development.

Recognizing that the humanization process comprises the interface established between phylogenesis (the history of an animal species), ontogenesis (the development of an individual within the species), and sociogenesis (the culture of a group), which makes each developmental phenomenon unique (microgenesis), considering our unique experiences in the collective experience, Vygotsky and his collaborators created a new statute in psychology and built a theoretical outline that would break up the space/time of that moment and influence many other generations of researchers.

In our group, we have revised these authors' texts, repeatedly reading their work as a way to develop research scopes that help us to understand an individual and to be in the world of children from the viewpoint of their social spatial life experiences. Among our studies, some concepts used by these authors have been essential for our reflection, such as our life experience (perezhivanie), environment (Sreda), and creation (VIGOTSKI, 2006, 2010, et al.).

At the time of writing this text, a research group is working on the conceptual systematization and techniques that we are agreeing to call life maps, experienced through pre-existing spaces, offered environments on a map sheet that is given to the research subjects, a point of departure for narratives and new representations, the chance to find that in between place that comprises a unit of an offered and experienced place.

Apart from life maps, we have tried to build other strategies such as "narrative photographs," "offers of thematic artifacts," "life experience models," and things produced by children in school such as texts, free maps, verbal creations, gestures and games, and drawings and drama work, specially focusing on intermodal relationships in the makeup of childhood compositions about their ideas of the world. All with the desire to understand and think of other possibilities of conceiving human spatialities, paths to reveal everyday life experiences that forge us and the ones we forge, conscious of the constant never-ending debate. Human sciences assume, therefore, their condition of humanity, as they do not refer to a mute object or a natural phenomenon; they refer to man's specificity. Man has the specificity of always expressing himself (speaking) or creating a text (if only potentially). "When man is studied outside the text and regardless of the text, we are no longer dealing with human sciences (but with anatomy, with human physiology, etc.)" (BAKTHIN, 1992, p. 406).

For us, it is a methodological option that shares the procedures identified above and adds space (and its expressions such as territory, place, and scenery) as a category for interpretation.

The choice of research grounded on interpretative assumptions opens various paths; moreover, working with those children's narratives means trying to understand their life experiences in their spatial contexts.

A meaning passed on by more ample contexts and revealed through their voices, through their utterances. After all, if the "the meaning of the word is totally determined by its context" (BAKTHIN, 1992, pg. 106), we can infer that "the acts of representation are always 
implied when one speaks or writes" (HALL, 1996, pg. 68). For Linhares (1999, pg. 21), "any place used already carries with it the hypothesis of legitimacy."

Working with research in human sciences is like coming across untrodden paths made by people whose mark on their histories and geographies are blended with a wider mark: one of the history of the place itself, of their contexts and the world.

\section{References}

BOGDAN, R.; BIKLEN, S. Investigação qualitativa em educação. [Qualitative Research in Education] Portugal: Porto, 1994.

BAKHTHIN, M. Estética da criação verbal. [The Esthetics of Verbal Creativity] São Paulo: Martins Fontes, 1992.

COULON, A. Etnometodologia.[Ethnomethodology] Petrópolis, RJ: Vozes, 1987.

FONTES, V. M. G. História e verdade. [History and Truth] Revista Ciências e Letras, Porto Alegre, nº. 18, pg. 115-132, 1997.

FRANCO, M. C. O conhecimento histórico e a questão das mediações. [The Knowledge of History and the Question of Mediations] Seminário sobre Teoria y Metodologia de las Ciencias y las Humanidades dos "Círculos Latinoamericanos de Refelxiones em Ciencias Sociales," Mexico School/ UNAM, May 1998.

HALL, S. Identidade cultural e diáspora [Cultural Identity and Diaspora]. Revista do Patrimônio Histórico e Artístico Nacional, [S.1.], nº 24, pg. 68-75, 1996.

LINHARES, C. Politicas do conhecimento: velhos contos, novas contas. [The Politics of Knowledge - Old tales and New Tales] Rio de Janeiro: Intertexto, 1999.

LOPES, J. J. M. De Malinovski a Bakhtin: as contribuições para o trabalho qualitativo. [Contributions to Qualitative Work] In: FREITAS, M. T. de A. Narrativas de professoras [Teachers' Narratives]. Rio de Janeiro: Ravil, 1998.

MARX, Karl. Preface to A Contribution to the Critique of Political Economy 1859. Available at: <http://www.histedbr. fae.unicamp.br/acer_fontes/acer_marx/tme_15.pdf $>$. Access on: Aug. 1, 2013.

MELLO, M. B. A zona de amplificação cultural: um estudo sobre a cognição infantil situada em contexto escolar. [ The Zone of Cultural Amplification: a study about child cognition in a school context] 2003. Tese (Doutorado) - Catholic Pontifical University of Rio de Janeiro, Rio de Janeiro, 2003.

VIGOTSKI, L. S. Obras Escogidas. [Collected Works] Madri: Machado Libros, 2006. Tomo IV.

VIGOTSKI, L.S. Quarta aula: a questão do meio na pedologia. [Lesson Four: the Question of Environment in Psychology] São Paulo: Psychology USP, 2010.

Received on: August 29, 2013

Accepted on: September 3, 2014 